\title{
Seasonal variation of algal diversity with reference to water quality in Jagadishpur Reservoir, Nepal
}

\author{
Sajita Pokhrel1, Narayan Prasad Ghimiree,", Shiva Kumar Rai² \\ ${ }^{1}$ Central Department of Botany, Tribhuvan University, Kirtipur, Kathmandu, Nepal, e-mail: sajupkrl@gmail.com (S.P.), \\ np.ghimire@cdbtu.edu.np (N.P.G., "corresponding author) \\ 2 Phycology Research Lab, Department of Botany, Post Graduate Campus, Tribhuvan University, Biratnagar, Nepal, \\ e-mail: sk.khaling@gmail.com (S.K.R.)
}

\begin{abstract}
The study of the importance of physicochemical parameters of water for algal growth and development in Jagdishpur Reservoir was carried out in the present research. Occurrence of algal species and values of water quality parameters also indicate the ecological nature and the present status of the reservoir. Water samples were collected from Jagdishpur Reservoir in Kapilvastu District (Nepal), in two seasons (wet and dry). The following physicochemical parameters of water were analyzed: temperature, $\mathrm{pH}$, dissolved oxygen, alkalinity, concentration of nitrates and phosphates, free $\mathrm{CO}_{2}$, hardness, conductivity, total dissolved solids. The values of free $\mathrm{CO}_{2}$, hardness, phosphate, temperature, and dissolved oxygen were high in wet season while alkalinity, nitrate, conductivity and total dissolved solid were high in dry season. Altogether 81 algal species belonging to 53 genera and 6 classes were recorded. Higher number of algal species was recorded in the dry season rather than in the wet season. The highest number of species was noted among Chlorophyceae, followed by Cyanobacteria $>$ Bacillariophyceae $>$ Euglenophyceae $>$ Crysophyceae and Dinophyceae. Cosmarium had the highest number of species (13) among all genera. During the wet season, Cosmarium, Calothrix and Phormidium were the genera with the highest number of species while Bulbochaete, Trachelomonas and Gomphonema were genera with the lowest number of species. During the dry season, Cymbella, Cosmarium and Rhopalodia were genera with highest number of species while Euglena, Gloeotrichia and Trachelomonas were genera with lowest number of species. Algal diversity was positively correlated with the increase of alkalinity, conductivity and TDS, while negatively correlated with free $\mathrm{CO}_{2}$, hardness, concerntration of phosphates and nitrates, $\mathrm{DO}, \mathrm{pH}$ and temperature. Shannon-Weiner diversity index value was higher during the dry season than in the wet season.
\end{abstract}

Key words: cyanobacteria, dry season, freshwater algae, physic-chemical parameters, wet season

\section{Introduction}

Wetlands are defined as: "Places where water is the primary factor controlling plant and animal life and the wider environment, where the water table is at or near the land surface, or where water covers the land" (Pittock et al. 2015). Wetlands have been described as "the kidneys of the landscape", because of their functions in the hydrological and chemical cycles and as "biological supermarkets" because of the extensive food webs and rich biodiversity they support (Mitsch and Gosselink 1993). They are also known as one of the world's most productive environments.

Phytoplanktons can serve as bio-indicators of environmental conditions in aquatic ecosystems because they grow quickly and respond rapidly to environmental change (Stoermer and Smol 1999).

Phytoplanktons are also important as they are the major producer in aquatic ecosystems, regulating the flow of energy and biomass to maintain the ecological balance (Cantonati et al. 2006). Occurrences of algal species also indicate the ecological nature and present status of the reservoir.

Nepal's wetlands, especially in the Terai region, were found to be the most vulnerable and threatened due to the habitat destruction and degradation, loss of ecosystem integrity, depletion of species abundance and diversity. Some studies of the ecology of Jagdishpur Lake have 
been conducted so far, but seasonality of the physicochemical parameters and algal diversity is still in shade. The lake is being degraded, due to anthropogenic as well as natural disturbances such as rapid expansion of invasive species, decreasing water level, encroachment, and increasing pollution by pesticides used by local farmers for crop protection from birds.

Jagdishpur Reservoir is one of the most important wetlands of Nepal, designated as Ramsar Site in 2003, and also highlighted in the Directory of Asian Wetlands. A very few attempts have been made to evaluate the ecological quality of wetlands using phytoplankton as scientific parameters for water quality, spatio-temporal variation of algal diversity and their relationship with environmental parameters. In this context, this study was intended to compare the physiochemical parameters and algal diversity between the dry and the wet season, as well as to seek the relationship between algal diversity and the physicochemical parameters in the Jagdishpur Lake system.

\section{Study area}

Jagdishpur Reservoir $\left(27^{\circ} 35^{\prime} \mathrm{N}\right.$ and $\left.83^{\circ} 05^{\prime} \mathrm{E}\right)$ lies in the Niglihawa Village Development Committee (Fig. 1), about $10 \mathrm{~km}$ north-west to Taulihawa the headquarters of Kapilvastu District, Nepal. It lies at low elevation (197 m a.s.l.) with a tropical monsoon climate of hot wet summer and cool, dry winter (DNPWC-IUCN 2003). Currently, it is the largest man-made reservoir in the country constructed for irrigation with a total area of 225 ha and water surface area of 157 ha (Rai and Paudel 2019). The water is fed by the Banganga River in the Churia catchment. The vegetation is mainly in a submerged succession stage with patches of floating species and reed swamp formations.

\section{Methods}

\section{Sample collection, preservation and identifi- cation}

Sample for this study were collected two times, once in wet season (August, 2020) and once in dry season (December, 2020) by quadrate method. Altogether 40 quadrats were sampled. The quadrat size was $1 \times 1 \mathrm{~m}$. From each site 5 samples were taken from shoreline and 5 samples were taken from a point $2 \mathrm{~m}$ distant from the shoreline towards the center of lake covering four sites of lake.

Before collection of samples, the water $\mathrm{pH}$, conductivity and total dissolved solid (TDS) were determined in situ by electric kit multi-parameter probe (Hanna Instruments). Temperature and dissolved oxygen (DO) were measured using optical Temperature meter (Ecosense ODO 200) and DO. Water samples for the analysis of total alkalinity, total hardness and dissolved oxygen were collected from the depth of $25 \mathrm{~cm}$, placed in plastic bottles, and carried to the laboratory of Central Department of Botany, Tribhuvan University. Laboratory analysis employed methods described in Clesceri et al. (1999), and Trivedy and Goel (1986).

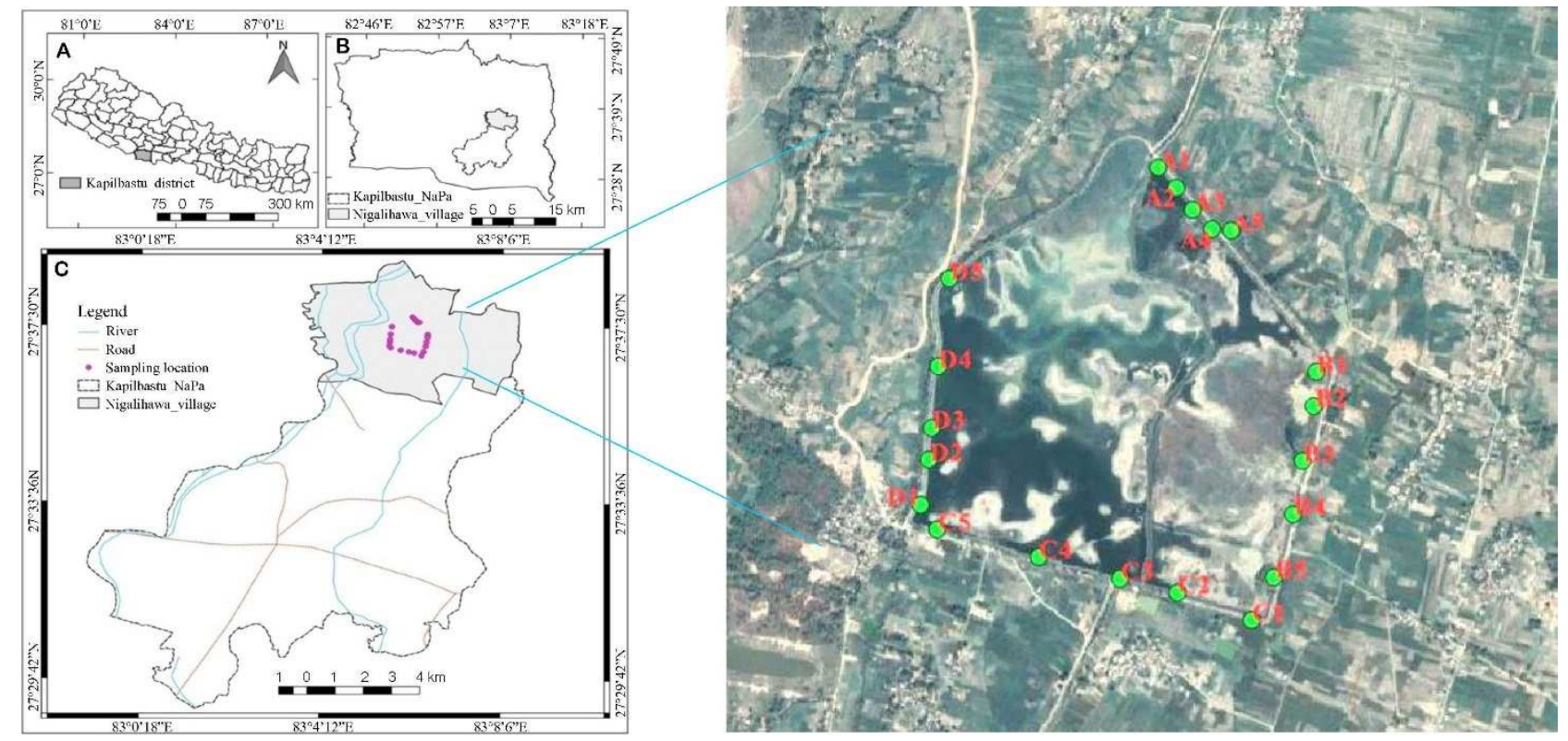

Fig. 1. Map of the study site showing the sampling points 
Planktonic algae were collected by a plankton net (mesh size of $10 \mu \mathrm{m}$ ), epiphytic forms by squeezing the roots of macrophytes while diatoms were collected with the help of tooth brush. Distinct, large filamentous algae were collected by free hand picking with the help of the forceps. Samples were preserved with 4\% FAA (Formalin Acetic Acid) solution.

For algal analysis, staining was done with $1 \%$ aqueous methylene blue solution for Cyanobacteria while iodine solution for Chlorophyceae family. Microphotograph were taken by Olympus trinocular microscope under $40 \times$ and $100 \times$ attached with Canon Power-shoot digital camera with micrometers. Taxonomic identification of algal taxa up to species level were done by following Prescott (1952), Scott and Prescott (1961), Philipose (1967).

\section{Data analysis}

Descriptive Analysis: Water parameters were tested through SPSS statistics version 23. Kolmogorov-Simrnov, significant values were used to test the normality of data distribution. Distribution of data was considered normal. One way ANOVA was done to compare the mean values of variables. Regression equations and graphs between physic-chemical parameters of water and species richness of algae of two seasons were drawn using Microsoft Office Excel - 2010.

Multivariate Analysis: The relationship between algal species and physico-chemical parameters was evaluated by multivariate analysis. Detrended correspondence analysis (DCA), a method of indirect gradient analysis was carried as the preliminary multivariate analysis. From the DCA ordination a gradient length of 3.676 SD units was obtained. Since, the gradient length of first axis was longer $(>2.5)$, so, canonical correspondence analysis (CCA) proved appropriate to explain the species - environment relationship [Braak 1986]. Package 'Vegan' of R Studio Version 3.4.4 was used to perform DCA and CCA Ordinations.

\section{Results}

\section{Physical and chemical parameters}

In the present study, the mean value of water temperature, $\mathrm{pH}, \mathrm{DO}$, free $\mathrm{CO}_{2}$, hardness and phosphate was higher in wet season than in the dry season, while the opposite was noted for TDS, conductivity, nitrate and Alkalinity. These differencies were significant for all the parameters except DO (ANOVA, p <0.05; Table 1).

Table 1. ANOVA table for environmental variables

\begin{tabular}{|c|c|c|c|c|c|}
\hline Parameter & Seasons & Mean & Std. Error & $\mathrm{F}$ & Sig. $(p)$ \\
\hline Free $\mathrm{CO}_{2}\left[\mathrm{mg} \mathrm{dm}^{-3}\right]$ & $\begin{array}{l}\text { Wet } \\
\text { Dry }\end{array}$ & $\begin{array}{l}227.17 \\
105.54 \\
\end{array}$ & $\begin{array}{l} \pm 6.95 \\
\pm 6.45 \\
\end{array}$ & 164.35 & 0.00 \\
\hline Hardness [mg dm${ }^{-3}$ ] & $\begin{array}{l}\text { Wet } \\
\text { Dry }\end{array}$ & $\begin{array}{l}314.6 \\
218.0 \\
\end{array}$ & $\begin{array}{c} \pm 18.69 \\
\pm 8.00 \\
\end{array}$ & 22.559 & 0.00 \\
\hline Alkalinity [mg dm$\left.{ }^{-3}\right]$ & $\begin{array}{l}\text { Wet } \\
\text { Dry }\end{array}$ & $\begin{array}{l}220.33 \\
313.25 \\
\end{array}$ & $\begin{array}{c} \pm 4.73 \\
\pm 11.48 \\
\end{array}$ & 54.08 & 0.00 \\
\hline Phosphate $\left[\mathrm{mg} \mathrm{dm}^{-3}\right]$ & $\begin{array}{l}\text { Wet } \\
\text { Dry }\end{array}$ & $\begin{array}{l}0.37 \\
0.12 \\
\end{array}$ & $\begin{array}{c} \pm 0.02 \\
\pm 0.0009\end{array}$ & 69.25 & 0.00 \\
\hline Nitrate $\left[\mathrm{mg} \mathrm{dm}^{-3}\right]$ & $\begin{array}{l}\text { Wet } \\
\text { Dry }\end{array}$ & $\begin{array}{l}0.05 \\
0.06 \\
\end{array}$ & $\begin{array}{l} \pm 0.0017 \\
\pm 0.0026 \\
\end{array}$ & 19.29 & 0.00 \\
\hline $\mathrm{DO}\left[\mathrm{mg} \mathrm{dm}^{-3}\right]$ & $\begin{array}{l}\text { Wet } \\
\text { Dry }\end{array}$ & $\begin{array}{l}4.59 \\
4.02 \\
\end{array}$ & $\begin{array}{l} \pm 0.200 \\
\pm 0.167 \\
\end{array}$ & 4.73 & 0.33 \\
\hline $\mathrm{pH}$ & $\begin{array}{l}\text { Wet } \\
\text { Dry }\end{array}$ & $\begin{array}{l}8.11 \\
8.00 \\
\end{array}$ & $\begin{array}{l} \pm 0.050 \\
\pm 0.053 \\
\end{array}$ & 66.06 & 0.00 \\
\hline Temperature $\left[{ }^{\circ} \mathrm{C}\right]$ & $\begin{array}{l}\text { Wet } \\
\text { Dry }\end{array}$ & $\begin{array}{l}33.13 \\
20.99\end{array}$ & $\begin{array}{c} \pm 0.26 \\
\pm 0.233\end{array}$ & 118.2 & 0.00 \\
\hline Conductivity $\left[\mu \mathrm{S} \mathrm{cm}^{-1}\right]$ & $\begin{array}{l}\text { Wet } \\
\text { Dry }\end{array}$ & $\begin{array}{l}295.1 \\
373.8 \\
\end{array}$ & $\begin{array}{c} \pm 6.87 \\
\pm 13.55 \\
\end{array}$ & 26.0 & 0.00 \\
\hline TDS [ppm] & $\begin{array}{l}\text { Wet } \\
\text { Dry }\end{array}$ & $\begin{array}{l}147.0 \\
188.0 \\
\end{array}$ & $\begin{array}{l} \pm 3.49 \\
\pm 6.70\end{array}$ & 28.87 & 0.00 \\
\hline
\end{tabular}

\section{Seasonal diversity of algae}

The total number of 81 species belonging to 53 genera and 6 classes was noted during two seasons in Jagadishpur reservoir. Twenty seven genera of Chlorophyceae were recorded, followed by Cyanobacteria (13 genera), Bacillariophyceae ( 9 genera), Euglenophyceae ( 2 genera) and Chrysophyceae (1 genera) / Dinophyceae (1 genera). Among all genera, the genus Cosmarium had the highest number of species (13), followed by Scenedesmus (6 species), Staurastrum (4 species), 
Chroococcus and Pediastrum (3 species each). Ankistrodesmus, Epithemia, Micrasterias and Oscillato-

ria (two species each). The other genera each had only one species each (Table 2, Plate 1 ).

Table 2. List of algae recorded in wet and dry season

\begin{tabular}{|c|c|c|c|c|}
\hline Name of species & Genera & Class & Wet & Dry \\
\hline 1. Anabaena sp. & Anabaena & Cyanobacteria & + & - \\
\hline 2. Ankistrodesmus falcatus & Ankistrodesmus & Chlorophyceae & + & + \\
\hline 3. Ankistrodesmus spiralis & Ankistrodesmus & Chlorophyceae & + & + \\
\hline 4. Arthrodesmus convergens & Arthrodesmus & Chlorophyceae & + & + \\
\hline 5. Bulbochaete sp. & Bulbochaete & Cyanobacteria & + & + \\
\hline 6. Calothrix sp. & Calothrix & Cyanobacteria & + & + \\
\hline 7. Chroococcus turgidus & Chroococcus & Cyanobacteria & + & + \\
\hline 8. Chroococcus minutus & Chroococcus & Cyanobacteria & + & + \\
\hline 9. Chroococcus schizodermaticus & Chroococcus & Cyanobacteria & + & + \\
\hline 10. Coelastrum sp. & Coelastrum & Chlorophyceae & - & + \\
\hline 11. Coelosphaerium dubium & Coelosphaerium & Cyanobacteria & + & + \\
\hline 12. Cosmarium contractum & Cosmarium & Chlorophyceae & + & + \\
\hline 13. Cosmarium dorsitruncatum & Cosmarium & Chlorophyceae & + & + \\
\hline 14. Cosmarium granatum & Cosmarium & Chlorophyceae & + & + \\
\hline 15. Cosmarium javanicum & Cosmarium & Chlorophyceae & + & + \\
\hline 16. Cosmarium obtusatum & Cosmarium & Chlorophyceae & + & + \\
\hline 17. Cosmarium portianum & Cosmarium & Chlorophyceae & + & + \\
\hline 18. Cosmarium subcrenatum & Cosmarium & Chlorophyceae & + & + \\
\hline 19. Cosmarium subprotumidum & Cosmarium & Chlorophyceae & + & + \\
\hline 20. C. lundellii var. ellipticum & Cosmarium & Chlorophyceae & + & + \\
\hline 21. C. quadrum var. quadrum & Cosmarium & Chlorophyceae & + & + \\
\hline 22. C. seelyanum & Cosmarium & Chlorophyceae & + & + \\
\hline 23. C. venustum var. basichondrum & Cosmarium & Chlorophyceae & + & + \\
\hline 24. C. venustum var. induratum & Cosmarium & Chlorophyceae & + & + \\
\hline 25. Crucigenia crucifera & Crucigenia & Chlorophyceae & + & - \\
\hline 26. Cymbella lange-bertalotii & Cymbella & Bacillariophyceae & - & + \\
\hline 27. Desmidium swartzii & Desmidium & Chlorophyceae & + & + \\
\hline 28. Dinobryon divergens & Dinobryon & Chrysophyceae & - & + \\
\hline 29. Encyonema silesiacum & Encyonema & Bacillariophyceae & - & + \\
\hline 30. Epithemia adnata & Epithemia & Bacillariophyceae & - & + \\
\hline 31. Epithemia sp. & Epithemia & Bacillariophyceae & - & + \\
\hline 32. Euastrum spinulosum & Euastrum & Chlorophyceae & + & + \\
\hline 33. Euglena polymorpha & Euglena & Euglenophyceae & + & + \\
\hline 34. Eunotia sp. & Eunotia & Bacillariophyceae & + & - \\
\hline 35. Fragilaria crotonensis & Fragilaria & Bacillariophyceae & + & + \\
\hline 36. Glaucocystis sp. & Glaucocystis & Chlorophyceae & + & - \\
\hline 37. Gloeotaenium loitlesbergereanum & Gleotanium & Chlorophyceae & - & + \\
\hline 38. Gloeotrichia raciborskii var. kashiensis & Gloeotrichia & Cyanobacteria & - & + \\
\hline 39. Gomphonema sp. & Gomphonema & Bacillariophyceae & + & + \\
\hline 40. Gomphosphaeria aponina & Gomphosphaeria & Chlorophyceae & - & + \\
\hline 41. Hyalotheca dissiliens & Hyalotheca & Chlorophyceae & + & - \\
\hline 42. Kirchneriella lunaris & Kirchneriella & Chlorophyceae & + & + \\
\hline 43. Lyngbya majuscula & Lyngbya & Cyanobacteria & + & - \\
\hline 44. Merismopedia elegans & Merismopedia & Cyanobacteria & + & + \\
\hline 45. Micrasterias foliacea & Micrasterias & Chlorophyceae & - & + \\
\hline 46. Micrasterias pinnatifida & Micrasterias & Chlorophyceae & + & + \\
\hline 47. Mougeotia sp. & Mougeotia & Chlorophyceae & - & + \\
\hline 48. Navicula radiosa & Navicula & Bacillariophyceae & + & + \\
\hline 49. Oedogonium sp. & Oedogonium & Cyanobacteria & + & + \\
\hline 50. Oocystis lacustris & Oocystis & Chlorophyceae & + & + \\
\hline 51. Oscillatoria amoena & Oscillatoria & Cyanobacteria & + & + \\
\hline 52. Oscillatoria limosa & Oscillatoria & Cyanobacteria & + & + \\
\hline 53. Pandorina morum & Pandorina & Chlorophyceae & + & - \\
\hline 54. Pediastrum duplex & Pediastrum & Chlorophyceae & + & + \\
\hline 55. Pediastrum tetras var. tetraodon & Pediastrum & Chlorophyceae & + & + \\
\hline 56. P. duplex var. subgranulatum & Pediastrum & Chlorophyceae & + & + \\
\hline 57. Peridinium sp. & peridinium & Dinophyceae & + & - \\
\hline 58. Phormidium sp. & Phormidium & Cyanobacteria & + & + \\
\hline 59. Pinnularia sp. & Pinnularia & Bacillariophyceae & + & + \\
\hline
\end{tabular}


continued of the Table 2

\begin{tabular}{lllcc}
\hline \multicolumn{1}{c}{ Name of species } & \multicolumn{1}{c}{ Genera } & Class & Wet & Dry \\
\hline 60. Rhopalodia gibba & Rhopalidia & Bacillariophyceae & - & + \\
61. Scenedesmus abundans & Scenedesmus & Chlorophyceae & + & + \\
62. Scenedesmus arcuatus var. platydiscus & Scenedesmus & Chlorophyceae & + & + \\
63. Scenedesmus bijugatus var. alternans & Scenedesmus & Chlorophyceae & + & + \\
64. S. bijugatus var. gravenitzii & Scenedesmus & Chlorophyceae & + & + \\
65. Staurodesmus cuspidatus var. divergens & Staurodesmus & Chlorophyceae & + & + \\
66. Staurastrum cf. tetracerum & Staurastrum & Chlorophyceae & + & + \\
67. Scytonema bohneri & Scytonema & Chlorophyceae & + & - \\
68. Sorastrum spinulosum & Sorastrum & Chlorophyceae & + & - \\
69. Sphaerocystis schroeteri & Sphaerocystis & Chlorophyceae & + & + \\
70. Spirogyra sp. & Spirogyra & Chlorophyceae & - & + \\
71. Spirulina subsalsa & Spirulina & Cyanobacteria & + & + \\
72. Staurastrum disputatum var. sinense & Staurastrum & Chlorophyceae & + & + \\
73. Staurastrum lapponicum & Staurastrum & Chlorophyceae & + & + \\
74. Staurastrum manfeldtii & Staurastrum & Chlorophyceae & + & + \\
75. Staurastrum orbiculare & Staurastrum & Chlorophyceae & + & + \\
76. Stigeoclonium sp. & Stigeoclonium & Chlorophyceae & - \\
77. Teilingia granulata & Teilingia & Chlorophyceae & - \\
78. Tetraedron tumidulum & Tetraedron & Chlorophyceae & - \\
79. Trachelomonas armata & Trachelomonas & Chlorophyceae & + \\
80. Ulnaria ulna & Ulnaria & Chlorophyceae & + \\
81. Zygnema sp. & Zygnema & Chlorophyceae & + \\
\hline
\end{tabular}

\section{Relation between algal diversity and physical and chemical parameters}

The species richness was shown to correlate positively with conductivity, $\mathrm{pH}$, TDS, concentration of nitrates and alkalinity. It correlated negatively with temperature, free $\mathrm{CO}_{2}$, concentration of phosphates, hardness and DO (Table 2). Phytoplankton diversity was increasing with increase of alkalinity, conductivity and TDS and decrease with increasing of free $\mathrm{CO}_{2}$, hardness, phosphate, nitrate, $\mathrm{DO}, \mathrm{pH}$ and temperature (Table 3, Figs 2-11).

Table 3. Correlation between species richness and physical and chemical parameters

\begin{tabular}{|c|c|c|c|c|c|c|c|c|c|c|c|}
\hline & Free $\mathrm{CO}_{2}$ & Hardness & Alkalinity & Phosphate & Nitrate & DO & $\mathrm{pH}$ & Temp. & Cond. & TDS & Sppn. \\
\hline Free $\mathrm{CO}_{2}$ & 1 & 0.41 & -0.39 & 0.41 & -0.27 & -0.01 & -0.58 & 0.77 & -0.29 & -0.28 & -0.33 \\
\hline Hardness & & 1 & -0.09 & 0.07 & -0.20 & -0.14 & -0.29 & 0.42 & 0.06 & 0.04 & -0.14 \\
\hline Alkalinity & & & 1 & -0.35 & 0.12 & -0.32 & 0.33 & -0.60 & 0.62 & 0.62 & 0.20 \\
\hline Phosphate & & & & 1 & -0.28 & 0.21 & -0.41 & 0.51 & -0.30 & -0.31 & -0.20 \\
\hline Nitrate & & & & & 1 & -0.17 & 0.26 & -0.40 & 0.32 & 0.34 & 0.09 \\
\hline DO & & & & & & 1 & -0.03 & 0.20 & -0.40 & -0.40 & -0.16 \\
\hline $\mathrm{pH}$ & & & & & & & 1 & -0.60 & 0.01 & 0.02 & 0.02 \\
\hline Temp. & & & & & & & & 1 & -0.53 & -0.55 & -0.40 \\
\hline Cond. & & & & & & & & & 1 & 0.99 & 0.46 \\
\hline TDS & & & & & & & & & & 1 & 0.45 \\
\hline Sppn. & & & & & & & & & & & 1 \\
\hline
\end{tabular}

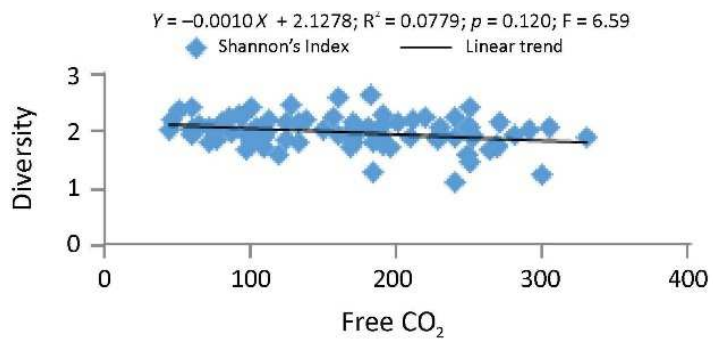

Fig. 2. Relationship between algal diversity and free $\mathrm{CO}_{2}$

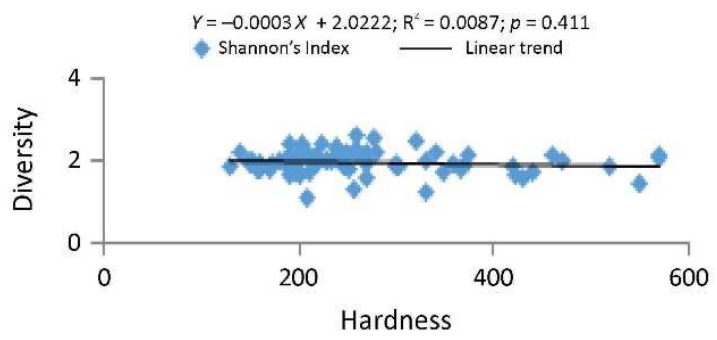

Fig. 3. Relationship between algal diversity and hardness 


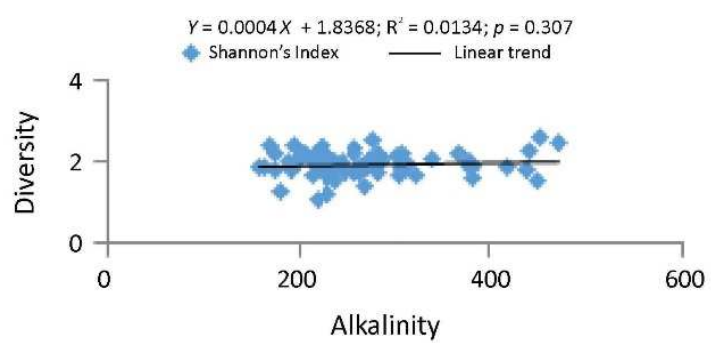

Fig. 4. Relationship between algal diversity and alkalinity

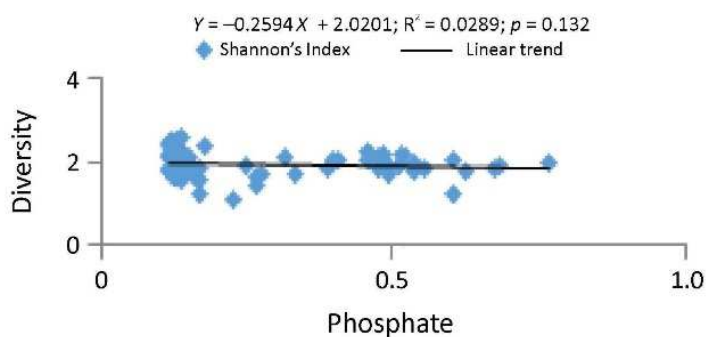

Fig. 5. Relationship between algal diversity and phosphate

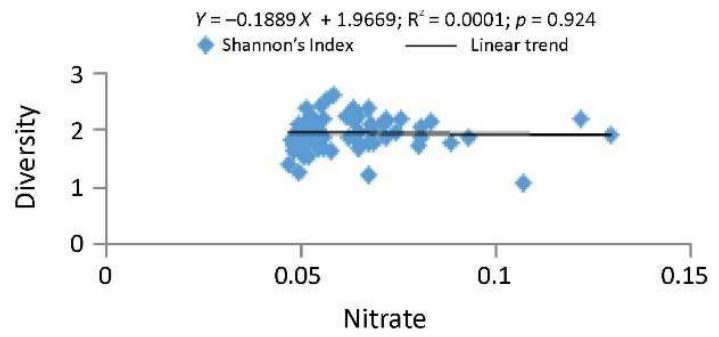

Fig. 6. Relationship between algal species richness and nitrate

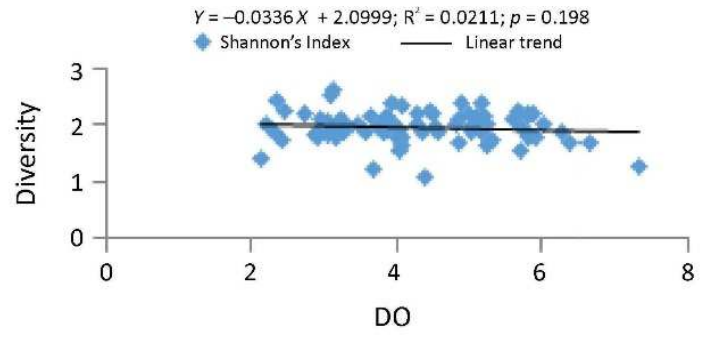

Fig. 7. Relationship between algal diversity and DO

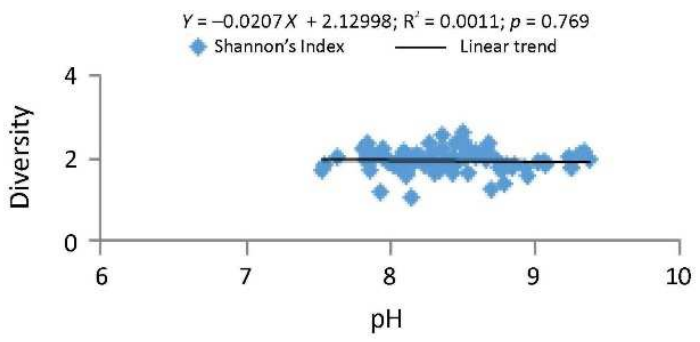

Fig. 8. Relationship between algal diversity and $\mathrm{pH}$

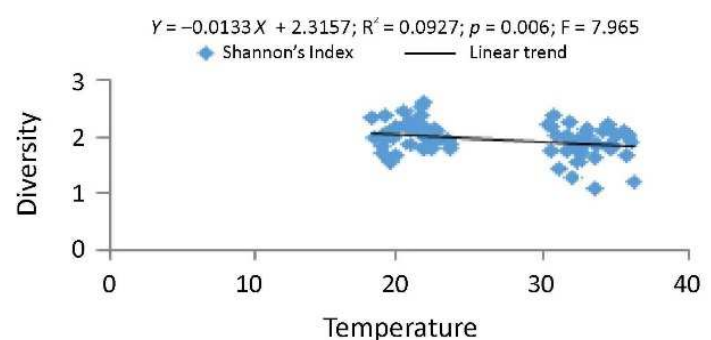

Fig. 9. Relationship between algal diversity and temperature

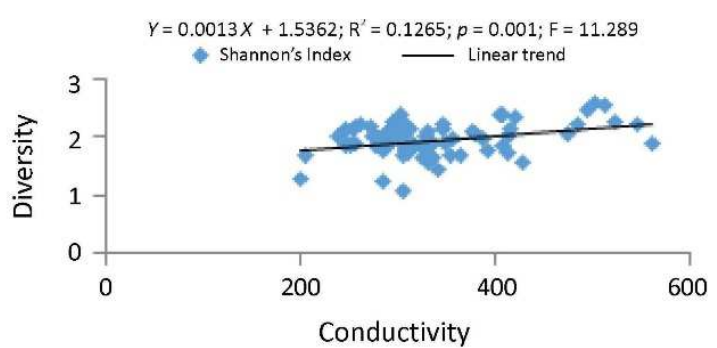

Fig. 10. Relationship between algal diversity and conductivity

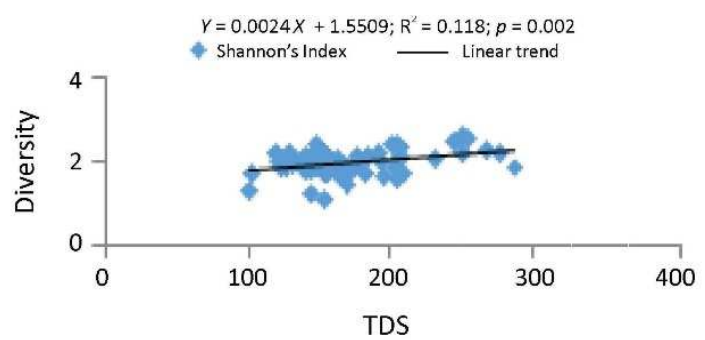

Fig. 11. Relationship between algal diversity and TDS

The CCA diagram showed Anabaena, Pandorina, Crucigenia, Calothrix, Glaucocystis, Hyalotheca, Lyngbya, Sphaerocystis, Trachelomonas and Phormidium correlated positively with temperature, free $\mathrm{CO}_{2}$, the concentration of phosphates and DO. Glaucocystis, Hyalotheca, Phormidium seemed to be more correlated with temperature and phosphate and Lyngbya was more correlated with free $\mathrm{CO}_{2}$. Crucigenia, Calothrix, Sphaerocystis were seemed to be more concentrated towards DO.

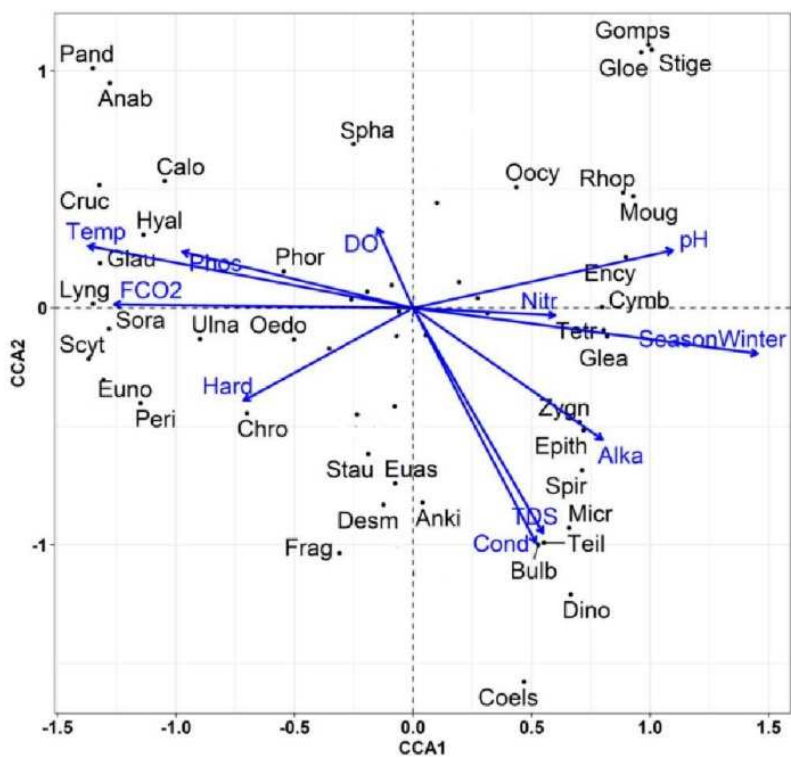

Fig. 12. CCA Biplot for algal genera along with environmental variables

Gloeotaenium, Epithemia, Bulbochaete, Zygnema, Spirogyra, Teilingia and Micrasterias positively correlated with alkalinity, TDS and conductivity and were negatively correlated with temperature, free 
$\mathrm{CO}_{2}$, concentration of phosphates and DO. Encyonema was placed along with $\mathrm{pH}$ on CCA diagram. Gloeotaenium, Gomphosphaerea, Tetraedron and Cymbella were positively related with the concentration of nitrates. Oedogonium, Ulnaria, Scytonema, Chroococcus, Eunotia, and Sorastrum were positively correlated with hardness (Fig. 12).

\section{Discussion}

\section{Physical and chemical parameters}

In the present study, the mean value of water temperature was higher in the wet season $(33.13$ $\left.\pm 0.26^{\circ} \mathrm{C}\right)$ than in the dry season $\left(20.99 \pm 0.23^{\circ} \mathrm{C}\right)$, which supported the results published by Gautam and Bhattrai (2008), Thapa and Saund (2013) and Chaudhary and Devkota (2018). However, the average temperature of the reservoir seems to be higher in the present study than in the previous ones. The highest value of TDS $(188 \pm 6.70 \mathrm{mg}$ $\mathrm{dm}^{-3}$ ) was observed in dry and the lowest (147 $\pm 3.49 \mathrm{mg} \mathrm{dm}^{-3}$ ) in the wet season, the results similar to those in Betana pond (Niroula et al. 2010) which is also tropical lake. TDS might be increased in water due to the intensification of the anthropogenic activity (Senthikumar and Sivakumar 2008). High rainfall and heavy inflow by canal to the reservoir might have reduced the TDS during the wet season and low rainfall and decreasing water level in the reservoir in the dry season might have increase the TDS. The mean value of conductivity was higher in the dry season $\left(373.8 \pm 13.55 \mu \mathrm{S} \mathrm{cm}^{-1}\right)$ than in wet season (295.1 $\left.\pm 6.87 \mu \mathrm{S} \mathrm{cm} \mathrm{cm}^{-1}\right)$. Similar result were reported by Gautam and Bhattarai (2008), but the average conductivity of the reservoir seems to have decreased in the present study comparison to values recorded by Thapa and Saund (2013). That may be determined by the decomposition of organic matter, input of ions, inlet, temperature of the water and total solids (Ghimire 2016). Lower conductivity in the wet season might be due to the dilution of water during the rainfall (Singh and Gupta 2010). The mean value of $\mathrm{pH}$ was higher in the wet season $(8.11 \pm 0.05)$ than in the dry season $(8.7 \pm 0.05)$. Similar results were obtained by Chaudhary and Devkota (2018) in the same reservoir but the average $\mathrm{pH}$ of the reservoir seems to be increased in the present study. It might be due to the increasing rate of photosynthetic activities which reduces the concentration of carbon dioxide and bicarbonates (Manjare et al. 2010). The mean value of DO was slightly higher in the wet season $\left(4.59 \pm 0.2 \mathrm{mg} \mathrm{dm}^{-3}\right)$ than in dry season $\left(4.02 \pm 0.17 \mathrm{mg} \mathrm{dm}^{-3}\right)$, which supported the results of Niroula et al. (2010).
The mean value of alkalinity was higher in the dry season $\left(313.25 \pm 11.48 \mathrm{mg} \mathrm{dm}^{-3}\right)$ than in the wet season $\left(220.33 \pm 4.73 \mathrm{mg} \mathrm{dm}^{-3}\right)$. Similar results had been reported byNiroula et al. (2010) and Chaudhary and Devkota (2018) for the same reservoir, but the average alkalinity of the reservoir seems to be increased in present study. This may be due to the concentration of major ions carbonate, bicarbonate, hydroxide, phosphate, nitrate and silicate. Higher alkalinity value in the dry season may be due to smaller water volume and more bicarbonate ions than in the wet season.

The mean value of free $\mathrm{CO}_{2}$ was higher in the wet season $\left(227.17 \pm 6.95 \mathrm{mg} \mathrm{dm}^{-3}\right)$ than in the dry season $\left(105.54 \pm 6.45 \mathrm{mg} \mathrm{dm}^{-3}\right)$, similar as in Thapa and Saund (2013) and Chaudhary and Devkota (2018), who studied the same reservoir However, in the present study, the average free $\mathrm{CO}_{2}$ of the reservoir was higher than in the previous studies. Free $\mathrm{CO}_{2}$ content in water increases with increase in temperature (Agrawal 1999). Maximum free $\mathrm{CO}_{2}$ during summer may be due to decomposition of organic matter by microbes at the bottom (Patra et al. 2010). The mean value of hardness was recorded higher in the wet season $\left(314.6 \pm 18.69 \mathrm{mg} \mathrm{dm}^{-3}\right)$ than in the dry season $\left(218 \pm 8 \mathrm{mg} \mathrm{dm}^{-3}\right)$. The same relation was noted by Dangol and Lacoul (1996), Offem et al. (2011) and Chaudhary and Devkota (2018). The high value of hardness in wet season may be due to high temperature, which increases the concentration of salts by excessive evaporation.The value of phosphate was higher in the wet season $\left(0.37 \pm 0.02 \mathrm{mg} \mathrm{dm}^{-3}\right)$ than the dry season $(0.12$ $\left.\pm 0.0009 \mathrm{mg} \mathrm{dm}^{-3}\right)$, similarly to the results of Pejaver et al. (2002) and Niroula et al. (2010). High concentration of phosphates during wet season may be due to agricultural runoff which carries fertilizers, increasing the nutrient content in the reservoir. Low concentration of phosphates during the dry season may be due to high rate of consumption by macrophytes and phytoplankton. The recorded concentration of nitrates was higher in the dry season $\left(0.06 \pm 0.0026 \mathrm{mg} \mathrm{dm}^{-3}\right)$ than in the wet season $\left(0.05 \pm 0.0017 \mathrm{mg} \mathrm{dm}^{-3}\right)$. Similar results were reported by Niroula et al. (2010), Thirupathaiah et al. (2012).

\section{Seasonal diversity of phytoplankton}

Algal diversity was found higher in the dry season than in the wet season, which was accordance with previous studies (Godar and Rai 2018; Shrestha and Rai 2017; Yuan et al. 2014; Fonseca and Bicudo 2011). It may be due to the dilution of the nutrients in the wet season (Nair et al. 1988). Only ten genera were reported exclusively 
during the wet season, which might be due to their physiological adaptations to high temperature, high concentration of free $\mathrm{CO}_{2}$ and phosphates, high value of hardness, $\mathrm{DO}$ and $\mathrm{pH}$, low TDS and conductivity. Ankistrodesmus, Merismopedia and Staurastrum were commonly seen in both dry and wet season as also reported by Shrestha and Rai (2017). Pediastrum was found in both seasons, like in the study of Tiwari and Chauhan (2006).

Most of the recorded species were present during both seasons, which indicated their broad ecological tolerance. The highest number of species was identified in the class of chlorophyceae, both in the wet and the dry season. Thapa and Saund (2013) stated that it was eutrophication that led to the increase in the number of species belonging to Chlorophyceae and their domination over other taxonomic groups of algae (Bhat et al. 2012). Tiwari and Chauhan (2006) have also shown the similar results depicting Chlorophyceae as the dominant class in the same reservoir.

The high number of species of Bacilliariophyceae in the dry season may be due to high TDS accumulated than in wet season, as TDS may support the growth of Bacilliariophyceae (Singh et al. 2010). The number of species of Cyanobacteria was higher in the wet season than in the dry season; similar results were reported by Mandal et al. (2016). In this study, six taxa of Scenedesmus were identified, reported previously by Rai and Paudel (2019) for same reservoir. Also the high number of species of genus Cosmarium noted in this study was similar to the results of Rai and Paudel (2019) ,Godar and Rai (2018) and Rai and Rai (2018) for Jagadishpur reservoir.

\section{Relation between algal diversity and physical and chemical parameters}

In present study, the species richness was higher during the dry season than during the wet season. Similar results were shown by Godar and Rai (2018), Fonseca and de Mattos Bicudo (2011) and Yuan et al. (2014). In the wet season, excessive flooding cause muddier water with less transparency which results in the death of algae with high light requirements. Godar and Rai (2018). Thus, the phytoplankton showed higher diversity during the dry season than in the wet season.
The CCA ordination showed that the variation of phytoplankton composition depended on physical and chemical parameters, which change with seasons. Temperature and DO have been shown to play a tremendous role in phytoplankton growth and abundance (Manigandan et al. 2018).

\section{Conclusions}

Water Temperature, $\mathrm{pH}, \mathrm{DO}$, free $\mathrm{CO}_{2}$, Hardness and Phosphate were recorded higher in wet season while TDS, Conductivity, Nitrate and Alkalinity were found higher in dry season. The number and types of algal species had changed according to the seasons. Higher number of phytoplankton species were recorded during dry season than wet season might be due to more fluctuations in water level during wet season and concentration of nutrients in dry season. Most of the recorded species were found in both season due to their resilience and tolerating ability to both harsh and suitable environment (changing season) for their growth and reproduction.

Dominance of algal class were in the order of Chlorophyceae > Cyanobacteria $>$ Bacillariophyceae $>$ Euglenophyceae $>$ Crysophyceae and Dinophyceae. Class Chlorophyceae and Bacilliariophyceae was found maximum during dry season due to increase of alkalinity, conductivity and TDS. High pH, temperature, hardness, DO, free $\mathrm{CO}_{2}$, phosphate and nitrare may be responsible for maximum growth of Cyanobacteria and Dinophyceae algae during the wet season. Further researchers are encouraged to focus on use and economic importance of phytoplankton.

\section{Acknowledgments}

We are thankful to the Central Department of Botany, Tribhuvan University, Kirtipur, Nepal for providinglab permission and supplied reagents, Post Graduate Campus Biratnagar for providing laboratory and President Chure -Terai Madesh Conservation Development Board for financial support. 


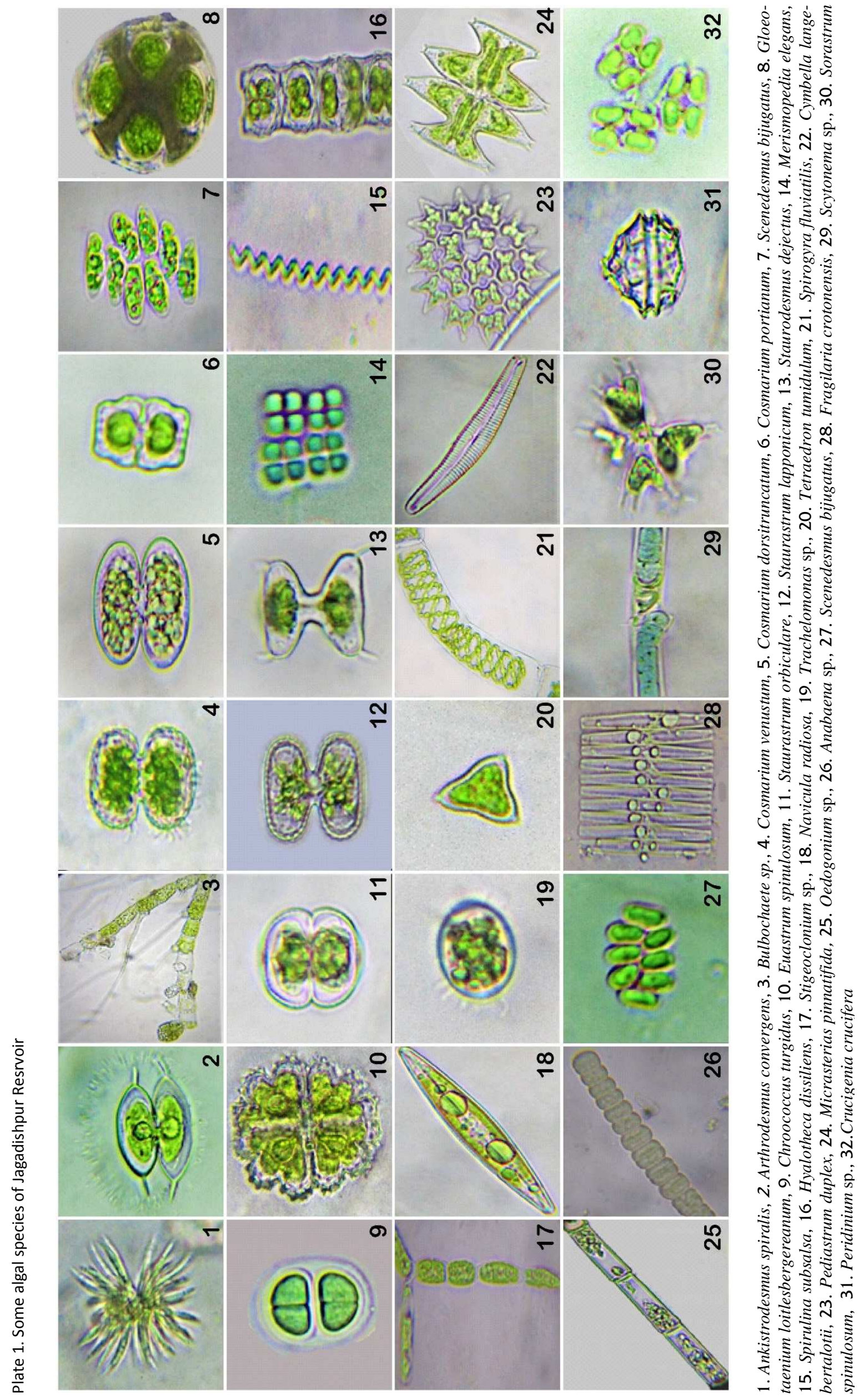




\section{References}

Agrawal S.C., 1999, Limnology. APH Publ. Corp., New Delhi, 132 pp.

Bhat N.A., Wanganeo A., Raina R., Dar J.A., Naik A.A., 2012, Phytoplankton diversity in relation to physicochemical characteristics of Upper Basin (Bhoj land), Bhopal, India, Curr. Biot. 6: 320-333.

Braak C.J., 1986, Canonical correspondence analysis: a new eigenvector technique for multivariate direct gradient analysis, Ecology 67(5): 1167-1179.

Cantonati M., Gerecke R., Bertuzzi E., 2006, Springs of the Alps, sensitive ecosystems to environmental change from biodiversity assessment to long-term studies, Hydrobiologia 562(1): 59-96.

Chaudhary R.K., Devkota A., 2018, Evaluation of Limnological Status of Jagadishpur Reservoir, Kapilvastu District, Nepal, Int. J. Appl. Sci. Biotechnol. (IJASTB) 6(3): 255-260.

Clesceri L.S., Greenberg A.E., Eaton A.D. (eds), 1999, Standard methods for the examination of water and wastewater, APHA-AWWA-WEF), Washington.

Dangol N.S., Locoul P., 1996, Growth and clump maintenance of Potamogeton cripus L. in Punymatiriver, Panauti, Nepal, [in:] Jha P.K., Ghimire G.P.S., Karmacharya S.B., Baral S.R., Lacoul P. (eds), Environment Biodiversity. In Context of South Asia, Ecological Society (ECOS), Kathmandu: 141-147.

[DNPWC-IUCN] Department of National Parks and Wildlife Conservation and International Union for Conservation of Nature, 2003, Information sheet on Ramsar Wetlands (RIS) - Jagdishpur Reservoir [Unpublished report submitted to the Ramsar Convention Bureau], Kathmandu, 8 pp.

Fonseca B.M., de Mattos Bicudo C.E., 2011, Phytoplankton seasonal and vertical Variations in a Tropical Shallow Reservoir with abundant macrophytes Ninfeias pond, Brazil, Hydrobiologia 665(1): 229245.

Gautam B., Bhattarai B., 2008, Seasonal changes in water quality parameters and sediment nutrients in Jagadishpur reservoir, a Ramsar site in Nepal, Nepal J. Sci. Technol. 9: 149-156.

Ghimire N.P., 2016, Physico-chemical characteristics and macrophytes of Pravas Lake in Palpa, Nepal, Int. J. Adv. Earth Environ. Sci. (IJAEES) 4: 14-18.

Godar K., Rai S.K., 2018, Freshwater green algae from Raja-Rani land, Bhogateni-Letang, Morang, J. Pl. Res. 16(1): 1-17.

Lacoul P., Freedman B., 2006, Environmental influences on aquatic plants in freshwater ecosystems, Environ. Rev. 14(2): 89-136.

Mandal R.B., Rai S., Shrestha M.K., Jha D.K., Pandit N.P., Rai S.K., 2016, Water quality and red bloom algae of fish ponds in three different regions of Nepal, Our Nature 14(1):71-77.

Manigandan V., Yosuva M., Saravanakumar A., Machendiranathan M., 2018, Seasonal influence of physicochemical parameters on phytoplankton diversity, community structure and abundance at Parangipettai
Coastal waters, Bay of Bengal, South East Coast of India, Oceanologia 60(2): 114-127.

Manjare S.A., Vhanalakar S.A., Muley D.V.,2010, Analysis of water quality usuing physicochemical parameters Tamdalge tank in Kolhapur District, Maharashtra, Int. J. Adv. Biotecnol. Res. 1(2): 115-119.

Mitsch W., Gosselink J., 1993, The value of Wetlands: Importance of scale and landscape setting, Ecol. Econ. 35(1): 25-33.

Nair K.C., Sankaranarayanan V.N., Gopalakrishnan T.C., Balasubramanian T., Lalilhambika D.T.V., Aravindakshan P., Krishnan K.M., 1988, Environmental conditions of some paddy-cum-prawn culture fields of Cochin backwaters, Southwest Coast of India, Indian J. Mar. Sci. 17: 24-30.

Niroula B., Singh K.L., Thapa G.B., Pal J., 2010, Seasonal variations in physic-chemical properties and biodiversity in Betana pond, Eastern Nepal, Our Nature 8(1): 212-218.

Offem B.O., Ayotunde E.O., Ikpi G.U., Ochang S.N., Ada F.B., 2011, Influence of seasons on water quality, abundance of fish and plankton species of IkworiLake, South-Eastern Nigeria, Fish. Aquacult. J. 2(1): 1-18.

Patra A., Santra K.B., Manna C.K., 2010, Limnological studies related to physico-chemical characteristics of water of Santragachi and Joypurjheel, WB, India, Our nature 8(1): 185-203.

Pejaver M.V., Somani U.V., Borkar M., 2002, Physicochemical studies of Lake Ambegosale, Thane, India, J. Ecobiol. 14(4): 277-281.

Philipose M.T., 1967, Chlorococcales. Monograph on algae, ICAR, New Delhi, 365 pp.

Pittock J., Finlayson M., Arthington A. H., Roux D., Matthews J. H., Biggs H., Harrison I., Blom E., Flitcroft R., Froend R., Hermoso V., Junk W., Kumar R., Linke S., Nel J., Nunes da Cunha C., Pattnaik A., Pollard S., Rast W., Thieme M., Turak E., Turpie J., van Niekerk L., Willems D., Viers J., 2015, Managing freshwater, river, land and estuarine protected areas, [in:] Worboys G.L., Lockwood M., Kothari A., Feary S., Pulsford I. (eds), Protected area governance and management, ANU Press, Canberra: 569-608.

Prescott G.W.,1952, Algae of the western Great Lakes area, WMC Brown, Dubuque: 977 pp.

Rai D.R., Rai S.K., 2018, Freshwater algae (excluding diatoms and red algae) from Hasina Wetland, Sundar Haraicha, Morang, Nepal, Hi. J. Sci. Technol. (HiJOST) 2: 1-12.

Rai S.K., Paudel S., 2019, Algal flora of Jagadishpurtal, Kapilvastu, Nepal, J. PI. Res. 17(1): 6-20.

Scott A.M., Prescott G.W., 1961, Indonesian desmids, Hydrobiologia 17(1-2): 1-132.

Senthilkumar R., Sivakumar K., 2008, Studies on phytoplankton diversity in response to abiotic factors in Veeranam lakes in the Cuddalore District of Tamil Nadu, J. Environ. Biol. 29(5): 747-752.

Sharma R.C., Tiwari V., 2018, Phytoplankton diversity in relation to physicochemical environmental variables of Nachiketa Tal, Garhwal Himalaya, Biodiversity Int. J. 2(6): 102-110. 
Shrestha G., Rai S.K., 2017, Algal flora of Rajarani Lake, Dhankuta and their seasonal distribution, Our Nature 15(1-2): 44-54.

Singh M., Gupta A., Beeteswari K., 2010, Physico-chemical properties of water samples from Manipur river system, India, J. Appl. Sci. Environ. Manage. (JASEM) 14(4): 85-89.

Stoermer E.F., Smol J.P., 1999, The Diatoms: Applications for the Environmental and Earth Science, Cambridge University Press, Cambridge-New York-Melbourne, $469 \mathrm{pp}$.

Temponeras M., Kristiansen J., Moustaka G.M., 2000, Seasonal variation in phytoplankton composition and physical-chemical features of the shallow lake Doirani, Macedonia, Greece, Hydrobiologia 424(1): 109-122.

Thapa J.B., Saund T.B., 2013, Water quality parameters and bird diversity in Jagdishpur Reservoir, Nepal, Nepal J. Sci. Technol. (NJST) 13(1): 143-155.
Thirupathaiah M., Samatha C.H., Sammaiah C., 2012, Analysis of water quality using physico-chemical parameters in lower Manair reservoir of Karimnagar District, Andhra Pradesh, Int. J. Environ. Sci. (IJES) 3(1): 172-180.

Tiwari A., Chauhan S.V.S., 2006, Seasonal phytoplanktonic diversity of Kitham Lake, Agra, J. Environ. Biol. 27(1): 35-38.

Trivedy R.K., Goel P.K., 1986, Chemical and biological methods for water pollution studies, Environmental Publications (Karad, India) 6: 10-12.

Yuan M., Zhang C., Jiang Z., Guo S., Sun J., 2014, Seasonal variations in phytoplankton community structure in the Sanggou, Ailian and Lidao Bays, J. Ocean Univ. China 13(6): 1012-1024. 